\title{
Moderní trendy v TPV
}

\author{
Konstantin Novikov ${ }^{1}$, Jana Kleinová ${ }^{1}$ \\ ${ }_{1}$ Západočeská univerzita v Plzni, Fakulta strojní, Katedra průmyslového inženýrství a \\ managementu \\ Univerzitní 8, 306 14, Plzeň, Česká republika \\ novikov@kpv.zcu.cz \\ kleinova@kpv.zcu.cz
}

\begin{abstract}
Anotace: Tento článek se zabývá moderními trendy $v$ technické přípravě výroby. Vychází z konceptu čtvrté průmyslové revoluce, která zásadně mění pojetí oblasti TPV. Jeho cílem je zhodnocení možnosti využití virtuální a rozšířené reality $v$ průmyslu. Především také zjištění, jak Ize tyto technologie využít $v$ TPV. Výsledkem by mělo být posouzení vhodnosti začlenění imerzních technologií do technologické přípravy výroby.
\end{abstract}

\section{1 Úvod}

Vlivem zvyšujících se požadavků na vývoj a inovace nových produktů na trzích se veškeré průmyslové podniky musí zabývat otázkou technické prípravy výroby. $O$ úspěchu a neúspěchu společnosti již nerozhoduje pouze cena a kvalita výrobků či náklady, ale i rychlost reakce podniků na požadavky zákazníků. Pokud jsme u prípravy výroby schopni pružnější a rychlejší reakce a zároveň dosahovat stejné kvality výroby $s$ nižšími náklady než naše konkurence, předpokládáme tak možnost vyšších zisků a lepší postavení společnosti v tržním prostředí.

V oblasti technické prípravy výroby dochází ke zvýšení náročnosti jednotlivých etap a současně je kladen dưraz na rychlé provádění této předvýrobní fáze. To je také důvodem, proč je vhodné využít moderních nástrojů, které by dokázaly pracovat s virtuálními (fyzicky neexistujícími) objekty. Tento prístup by umožnil paralelní provádění jednotlivých etap technické prípravy výroby, což by výrazně zkrátilo čas potřebný pro přípravu.

\section{2 Životní cyklus produktu}

Každý produkt má svůj specifický životní cyklus. Prochází různými fázemi vývoje, které jsou pro jednotlivé produkty jinak náročné a dlouhé. Zjednodušeně Ize říci, že životní cyklus začíná obdobím výzkumu a vývoje a pokračuje přes výrobu až k využití produktu na trhu, jak Ize vidět na Obrázku 1. 


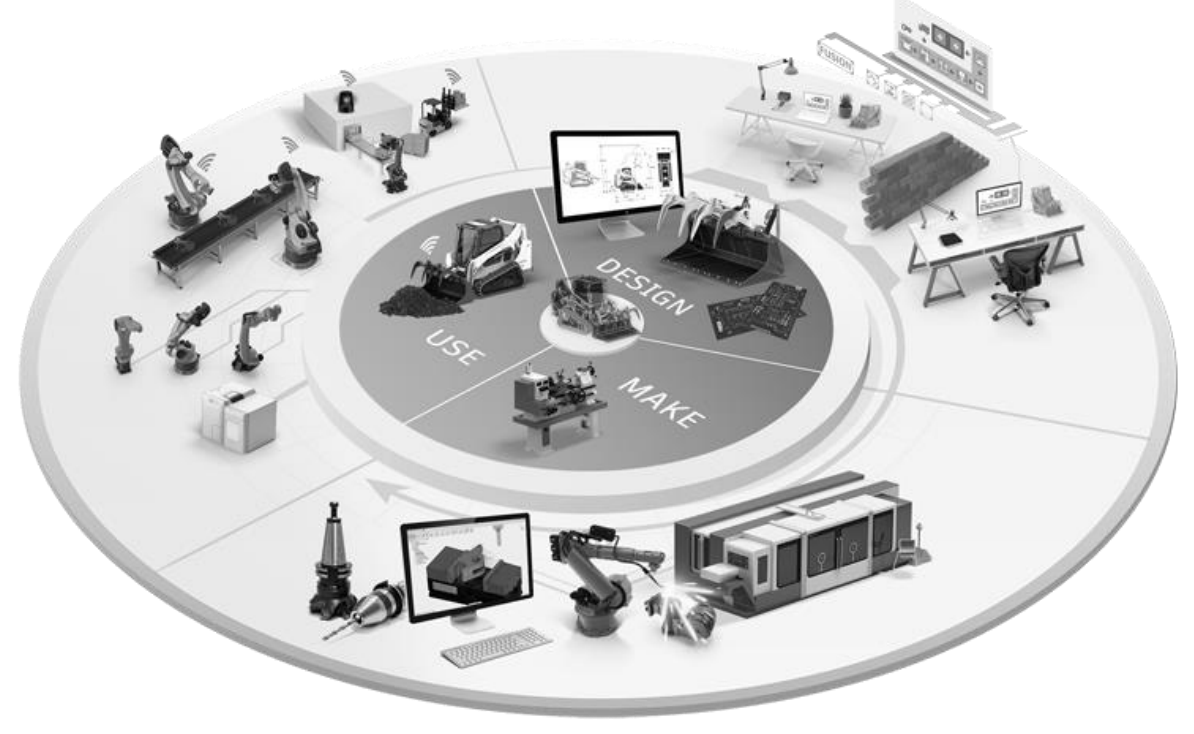

Obrázek 1 - Životní cyklus produktu

Nejdřive je vhodné si vysvětlit, jakým způsobem je definován produkt a jakými zpưsoby Ize na životní cyklus pohlížet.

\subsection{Produkt}

Produkt je základním stavebním kamenem všech výrobních podniků a měl by být středem pozornosti všech pracovníků. Produkt významně ovlivňuje dosahování základních podnikatelských cílů. Kvalitní řízení produktů umožňuje uspokojit potřeby zákazníků, což je hlavním cílem každé výrobní společnosti, která chce uspět na trhu. Produkt je základní součástí marketingového mixu všech podniků a obsahuje čtyři marketingové nástroje: produkt (Product), cenu (Price), místo (Place) a propagaci (Promotion).

\subsection{Pohledy na životní cyklus produktu}

Na životní cyklus produktu Ize pohližet několika způsoby dle konkrétní oblasti zájmu. Pro účely této práce je nejdříve nutné vybrat vhodný přistup a dále specifikovat, ve které fázi životního cyklu se budeme dále pohybovat.

Odborná literatura nabízí velké množství pohledů na životní cyklus produktu. Autor se přiklání k rozdělení dle Roubala (2010), který tyto pohledy strukturoval následovně:

- pohled z hlediska odbytového množství - marketingový pohled,

- pohled z hlediska životnosti jednotlivého produktu,

- pohled $z$ hlediska místa realizace jednotlivých etap,

- pohled $z$ hlediska jednotlivých transformačních procesů,

- $\quad$ pohled z hlediska dopadu výrobku na životní prostředí,

- integrovaný pohled na životní cyklus produktu,

- ekonomický pohled na životní cyklus produktu. [1] 
Z hlediska provádění výrobních procesů si autor zvolil pohled týkající se místa realizace jednotlivých etap, jak je možné vidět na Obrázku 2. Tento pohled se totiž zaměřuje na prípravu samotné výroby, která má zásadní vliv na efektivitu provádění výrobních procesů.

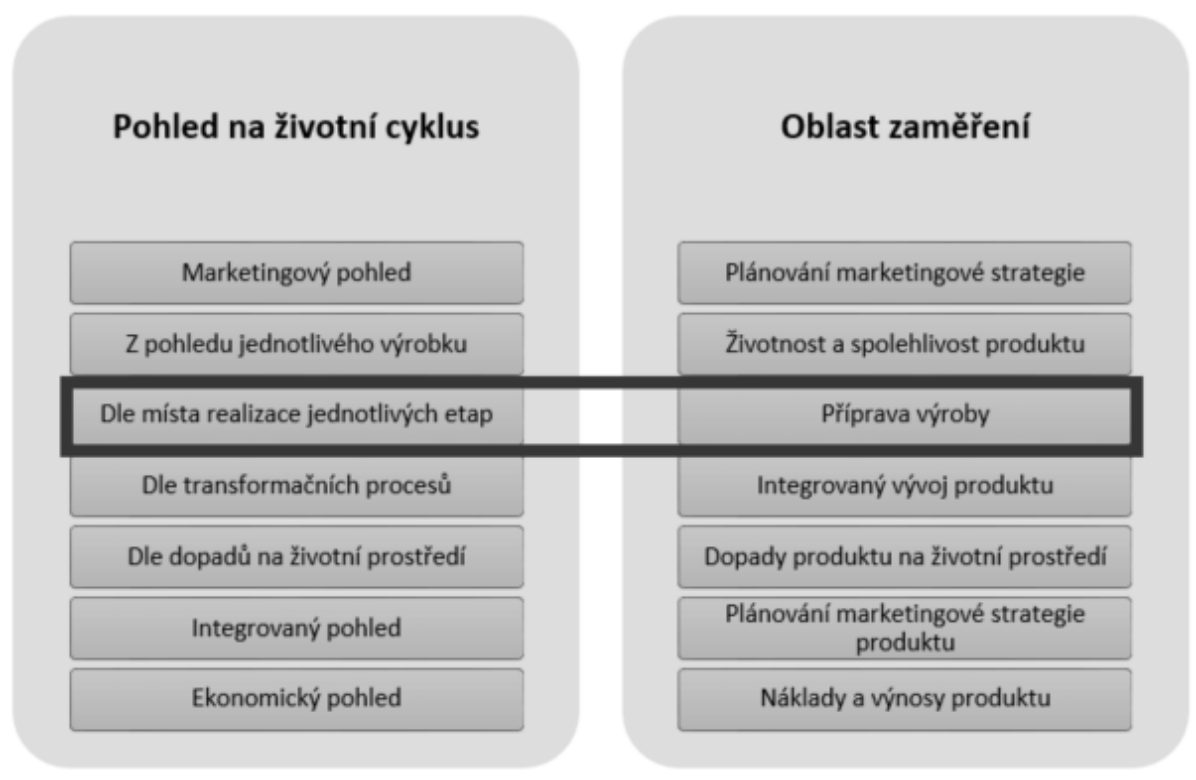

Obrázek 2 - Pohledy na životní cyklus

Z Obrázku 3 je vidět, že tento pohled uvažuje šest základních míst realizace během životního cyklu výrobku. Jsou to:

- management,

- technická príprava výroby,

- výrobní dílna,

- mezi dílnou a zákazníkem,

- u zákazníka,

- $\quad$ v místě likvidace. 


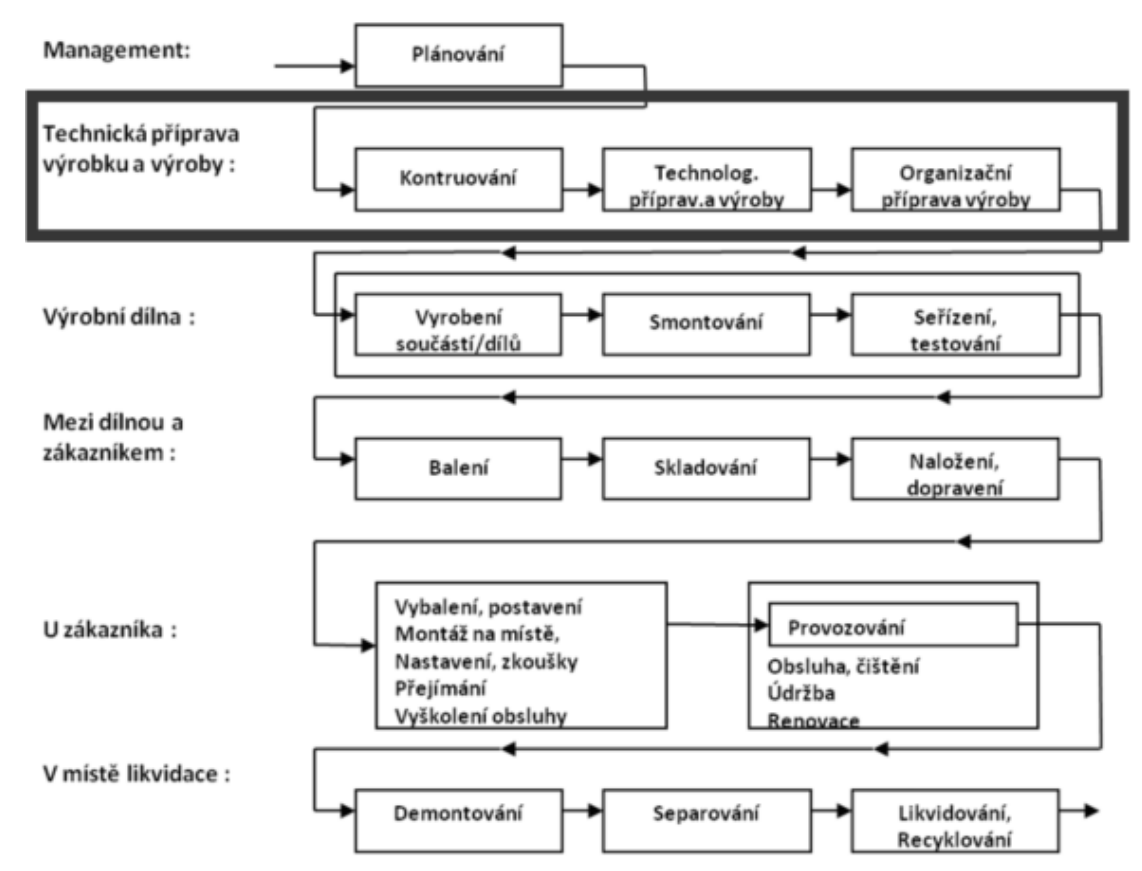

Obrázek 3 - Výběr oblasti životního cyklu produktu

Procesy, prímo související $s$ výrobou, jsou prováděny $v$ místě výrobní dílna, případně mezi dílnou a zákazníkem. Nicméně, z pohledu odborné literatury a získaných zkušeností, až $80 \%$ výrobních nákladů Ize nejvíce ovlivnit $\mathrm{v}$ předvýrobních etapách. $V$ těchto etapách, dle [2] a [3], také vzniká až $75 \%$ různých chyb, které ovlivňují kvalitu produktu, čas výroby i náklady potřebné pro výrobu. $V$ těchto předvýrobních etapách se většinou jedná o projektově rízené aktivity, které jsou jedinečné, tudíž s sebou přináší i velkou míru rizika. [4]

\section{Technická príprava výroby}

Technická príprava výroby je velice důležitou součástí životního cyklu produktu, která významně ovlivňuje funkce výrobních procesů a má zásadní vliv na výrobek $z$ hlediska kvality, času a nákladů. $V$ dalších podkapitolách je popsána príprava výroby jako etapa předvýrobní fáze a jsou zde identifikovány její nedílné součásti. Obecný průběh přípravy výroby je zachycen na Obrázku 4.

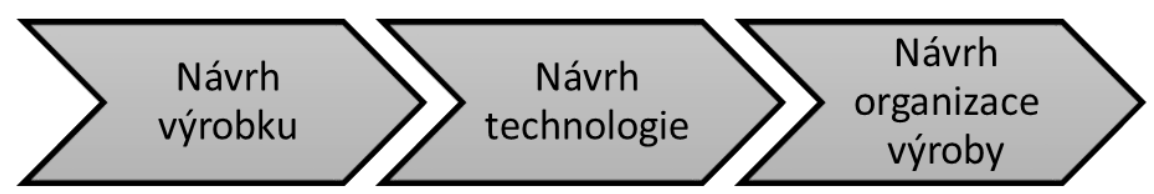

Obrázek 4 - Průběh přípravy výroby

Príprava výroby zahajuje a sjednocuje celý výrobní systém. Jsou zde stanoveny základy, které budou mít vliv na úspěšnost výrobku na trhu. Během vývoje a př́pravy každého výrobku však vznikají často chyby, které se projevují jako změny ve výrobním procesu nebo se z nich stávají nedokonalosti, jež mohou zákazníka odradit. S poměrně nízkými náklady Ize 
pomocí konstrukčního a technologického řešení docílit eliminaci negativních dopadů. To je hlavní důvod, proč je potřeba se důkladně zaměřovat na zdokonalování procesů výroby již $v$ předvýrobních fázích. Samozřejmě můžeme při vývoji produktu nebo přípravě výrobku zamezit vzniku problémů, ne vše jde ale $v$ této fázi odhalit. [5]

\section{1 Členění TPV}

Odborná literatura se na členění technické přípravy výroby dívá více pohledy. Přestože se jednotlivé pohledy mohou lišit, jejich podstata zůstává podobná. Starší literatura většinou uvádí pouze konstrukční a technologickou príipravu výroby. Heřman (2001) například rozděluje TPV na 4 fáze (konstrukční, technologická, materiálová a organizační príprava). Jednotlivé pohledy je možné vidět na Obrázku 5.

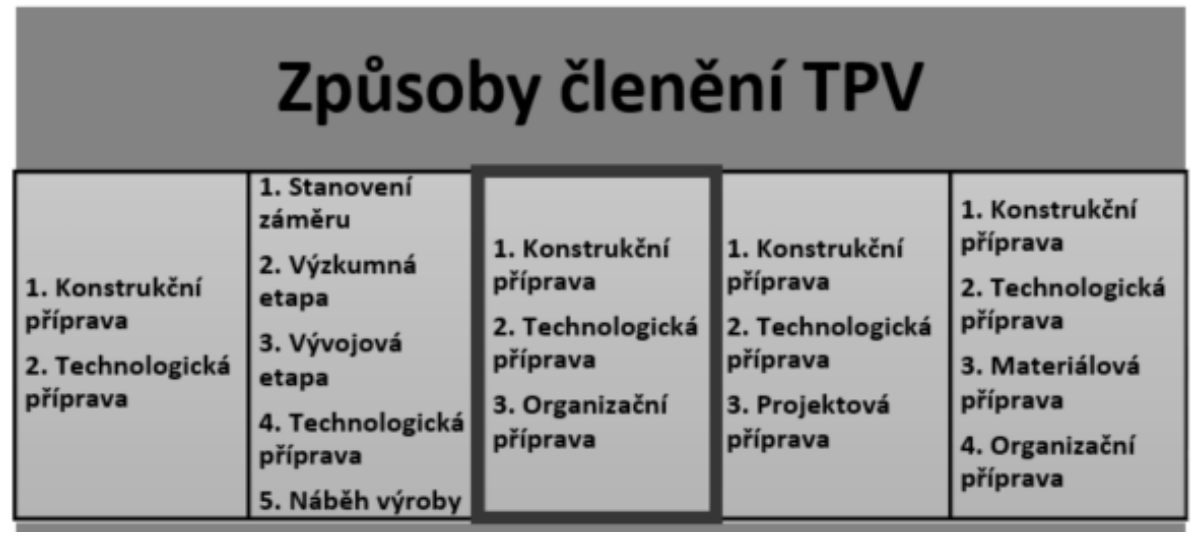

Obrázek 5 - Členění TPV

Autor se přiklání k členění dle Jurové [6], která technickou prrípravu výroby rozděluje na následující části:

- konstrukční príprava,

- technologická príprava,

- organizační př́prava.

Toto rozdělení je dostatečně podrobné a nezapomíná na důležitost organizační přípravy výroby, jež v některých literaturách chybí.

Etapa konstrukční prípravy výroby navazuje na marketingový průzkum trhu. Zabývá se konstruováním nových nebo zdokonalováním stávajících výrobků. Cílem této etapy je dosažení funkčně co nejlepšího, provozně co nejekonomičtějšího, konstrukčně co nejjednoduššího a po designové stránce odpovídajícího výrobku dle zadaných požadavků. Výrobní náklady konkrétního výrobku se již odráží $v$ této etapě prípravy výroby a značně ovlivňují budoucí výrobu. [5]

Technologická příprava výroby definuje způsob, jakým se budou provádět jednotlivé výrobní operace. Během těchto operací bude docházet ke změně tvaru či látkové podstaty materiálu, přičemž přeměna tvaru zajistí konečný prodejný produkt. Tato etapa přípravy výroby určuje sekvenci operací, 
výrobních strojů či zařízení, na nichž bude transformace ze surových tvarů probíhat $s$ ohledem na stroje, prípravky, potřebná měřidla. $S$ technologickou př́pravou výroby je kromě technologických aspektů výrobního procesů rovněž spojeno zajištění bezpečnosti, hygieny a kultury práce. [5]

Základním organizační prípravy výroby je sladit všechny předešlé etapy prípravy výroby $s$ dưrazem na informační a hmotné toky. Zásadní pro harmonizaci je, aby výroba probíhala plynule a bez rušivých vlivů a zároveň co nejproduktivněji. Výstupem organizační prípravy výroby by měla být dokumentace, která kopíruje materiálový tok přes jednotlivá pracoviště. Dále je důležité do materiálového toku zaznamenat jeho intenzitu a rychlost $s$ ohledem na objem výroby. $\mathrm{Na}$ konci této etapy se provádí ověření a odzkoušení navrhovaného řešení. [5]

\subsection{Vývoj TPV}

$\checkmark$ této kapitole by chtěl autor interpretovat jeho názor na vývoj a změnu pojetí technické prípravy výroby. Klasické pojetí TPV (viz Obrázek 6) pracuje $s$ jednotlivými etapami jako s oddělenými celky. Když je první hotov, může se začít pracovat na dalším. To by nebyl až takový problém, dokud bude příprava výroby jednoduchá.

V současnosti, kdy jsme již vstoupili do čtvrté průmyslové revoluce, vzniká tendence eliminovat a zjednodušovat veškeré činnosti, které jsou prováděny lidským personálem. To má však obrácený efekt na technickou přípravu výroby. Složitost a komplexnost této předvýrobní fáze výrazně roste, což na druhou stranu prodlužuje a komplikuje její provádění. Se složitostí se prodlužují samotné etapy TPV, ale jejich překrytí je minimální.



Obrázek 6 - Důsledek rostoucích nároků na trvání TPV

Abychom dokázali efektivně uspokojovat požadavky na 3 klíčové faktory, jimiž jsou kvalita, čas a náklady, je potřeba provádět tyto jednotlivé etapy současně. Zde se již předpokládá multidisciplinární spolupráce pracovníků z různých oddělení. 


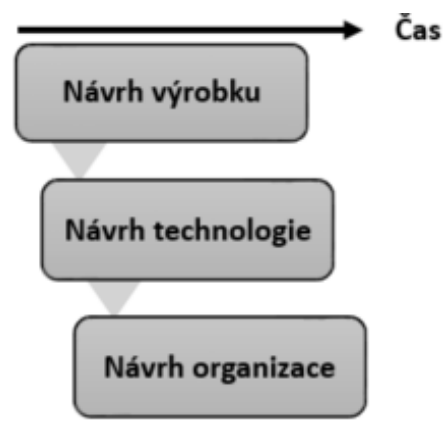

Obrázek 7 - Paralelizace činností TPV

Navíc je potřeba využívat moderní technologie, které dosud $v$ prípravě výroby nebyly až tak běžné. Moderními technologiemi jsou myšleny především nástroje, jež umožní práci s virtuálními - nefyzickými objekty. Tyto nástroje umožní paralelní provádění všech etap (viz Obrázek 7) a tím i rychlejší a efektivnější připravení výroby.

\section{$4 \quad$ Moderní trendy v TPV}

Na úvod této kapitoly je důležité si vysvětlit, co konkrétně autor myslí pod pojmem moderní trendy. Jak již vyplývá z předchozí kapitoly, jedná se především o imerzní technologie, kterými dle literatury [7] jsou:

- Virtuální realita

- Rozšířená realita

- Smíšená realita

Vzhledem $\mathrm{k}$ tomu, že definice smíšené reality není jednoznačná a spíše zahrnuje vše, co se nachází mezi čistě skutečným světem a virtuálním prostředím, přiklání se autor k názoru Hořejšího [8] a bude tak dále pracovat pouze s pojmy virtuální a rozšířená realita.

\subsection{Virtuální realita}

Přiřazení univerzální definice pojmu virtuální realita je poměrně složité, jelikož se definice různých autorů často liší. Obecně Ize virtuální realitu chápat jako typ počítačové technologie, která pomocí smyslů člověka umožňuje uživateli nasimulovat reálné prostředí nebo imaginární svět. Vnímání virtuální reality umožňuje vnoření a obklopení pozorovatele virtuálním světem. [9] 


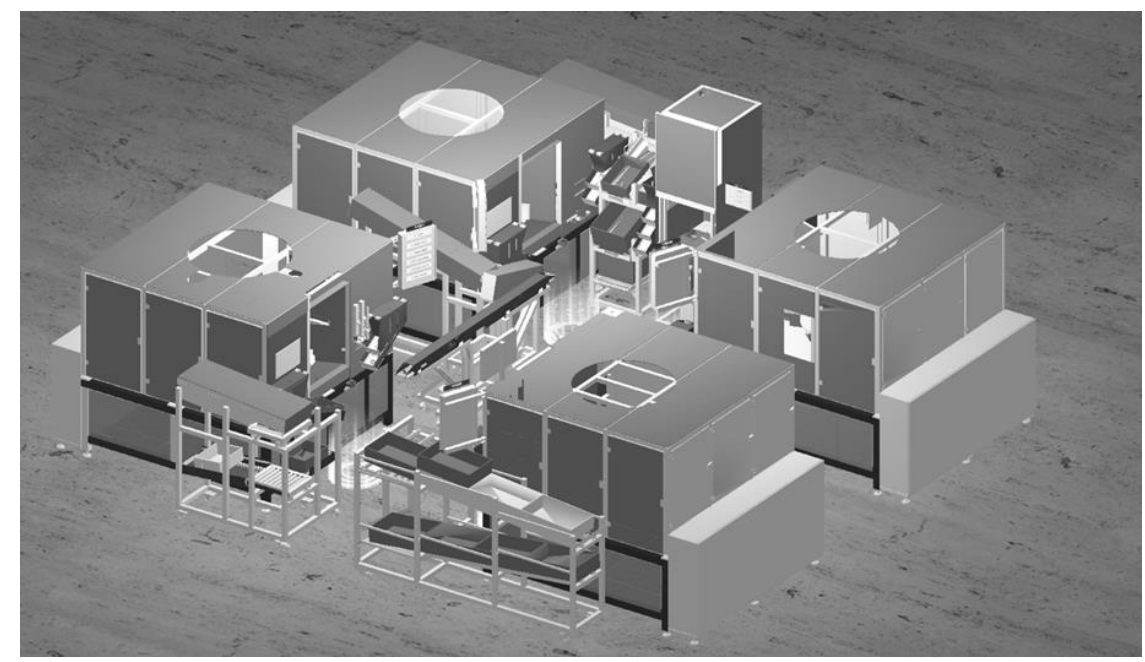

Obrázek 8 - Ukázka z prostředí VR

Virtuální realitu je možné popsat jako počítačem vytvořené interaktivní a trojrozměrné prostředí, do něhož je uživatel zapojený. Ukázka takového prostředí je vidět na Obrázku 8. Pro zapojení uživatele se využívají různá média. Mohou to být náhlavní displeje, chytré brýle nebo jen monitor.

\subsection{Rozšířená realita}

Pojem rozšiřená realita není natolik známý jako virtuální realita. Obecně Ize říci, že se jedná o reálný obraz doplněný virtuálními prvky. Spojuje prvky generované počítačem s informacemi ze skutečného světa. Rozšiřená realita umožňuje propojovat virtuální objekty s reálným světem a to $v$ reálném čase. [9]

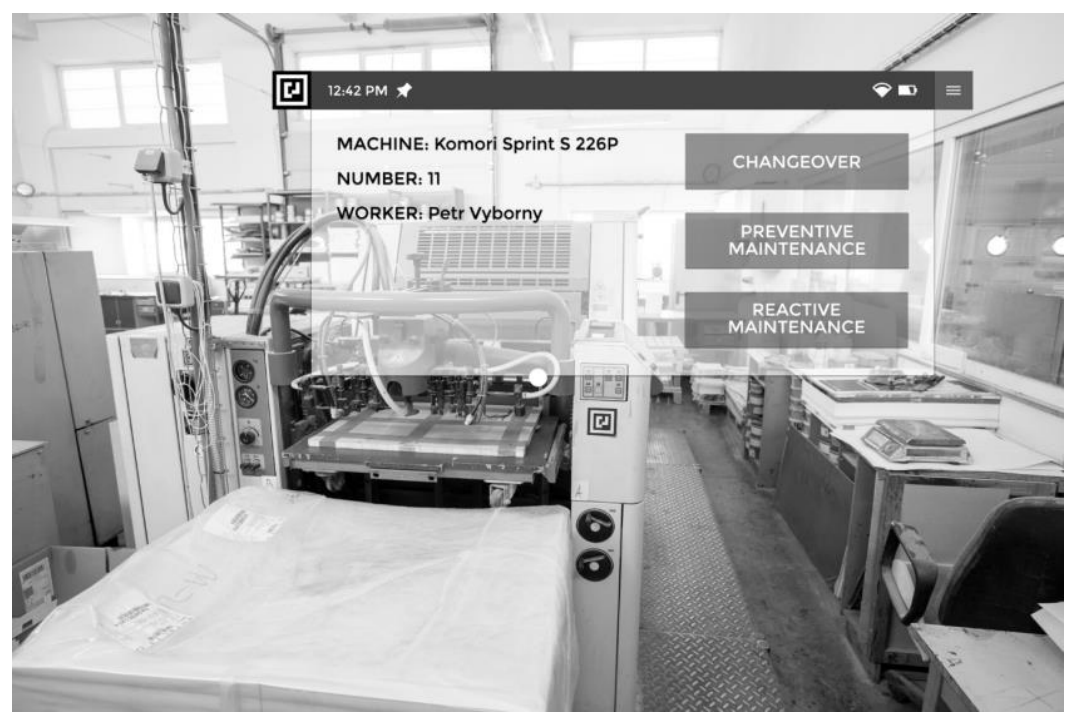

Obrázek 9 - Ukázka z prostředí AR

$S$ termínem rožsiřená realita se dnes často setkáváme, jelikož se jedná o atraktivní technologii s početnými možnostmi komerčního využití. Pro zobrazení reality s následným přidáním virtuálních digitálních prvků můžeme využívat chytré telefony, tablety, poloprůhledné brýle či kameru ve spojení se 
zobrazovacím zařízením. Ukázku z prostředí rozšířené reality, která pro zobrazení využívá brýle Hololens od společnosti Microsoft, Ize vidět na Obrázku 9.

\subsection{Využití VR a AR v TPV}

Jak již bylo zmíněno, technická príprava výroby zažívá s příchodem nových moderních technologií velký pokrok. $S$ tím souvisí i využití právě virtuální a rozšířené reality $v$ této oblasti. Úkolem moderních technologií je pak nejen zkrátit čas trvání činností prípravy výroby ale i zvýšit kvalitu výstupů a sniźit náklady na nedostatky, které by se projevily během samotné výroby.

Obecné možnosti využití VR a AR ve vazbě na podnikové činnosti, které Ize vidět na Obrázku 10, rozděluje [8] na 5 základních oblastí.

\begin{tabular}{|c|c|c|c|c|}
\hline $\begin{array}{l}\text { Návrh } \\
\text { a vývoj }\end{array}$ & Logistika & Výroba & $\begin{array}{l}\text { Provoz } \\
\text { a údržba }\end{array}$ & $\begin{array}{l}\text { Vsechny } \\
\text { etapy }\end{array}$ \\
\hline $\begin{array}{c}\text { Virtuální } \\
\text { konstruování }\end{array}$ & $\begin{array}{l}\text { Navigace } \\
\text { po skladu }\end{array}$ & $\begin{array}{l}\text { Manuály } \\
\text { a návodky }\end{array}$ & $\begin{array}{l}\text { Manuály } \\
\text { a návodky }\end{array}$ & $\begin{array}{l}\text { Virtuálni } \\
\text { kolaborace }\end{array}$ \\
\hline $\begin{array}{l}\text { Návrh a prohlidky } \\
\text { layoutu }\end{array}$ & Pick-By-Vision & Trénink & Trénink & $\begin{array}{c}\text { Vizualizace } \\
\text { dat }\end{array}$ \\
\hline $\begin{array}{l}\text { Virtuální } \\
\text { simulace }\end{array}$ & $\begin{array}{l}\text { Vizualizace } \\
\text { nakládky }\end{array}$ & $\begin{array}{c}\text { Porovnávání } \\
\text { odchylek }\end{array}$ & $\begin{array}{l}\text { Prediktivní } \\
\text { údržba }\end{array}$ & Marketing \\
\hline $\begin{array}{c}\text { Ergonomické } \\
\text { studie }\end{array}$ & & $\begin{array}{l}\text { Doplnění } \\
\text { metadat }\end{array}$ & & \\
\hline \multicolumn{5}{|l|}{ Vysvětlivky: } \\
\hline \multicolumn{5}{|c|}{ Možnost využití VR pro danou aplikaci v rámci etapy PLC } \\
\hline \multicolumn{5}{|c|}{ Možnost využití AR pro danou aplikaci v rámci etapy PLC } \\
\hline
\end{tabular}

Obrázek 10 - Využitelnost VR a AR v prümyslu [8]

Podobným způsobem Ize vytvořit matici použitelnosti VR a $A R$ v technické prípravě výroby. Ovšem ne na všechny činnosti technické př́ipravy výroby se použití moderních technologií hodí. Proto je nejdříve nutné definovat oblasti TPV, kde je použití virtuální a rozšiřené reality možné a vhodné. 
Tabulka 1 - Využitelnost VR a AR v TPV

\begin{tabular}{|c|c|c|c|}
\hline Etapa TPV & Činnost & Virtuální realita & Rozšířená realita \\
\hline \multirow{5}{*}{ 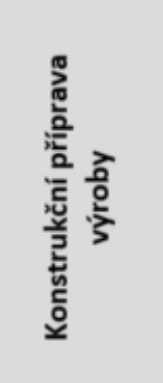 } & Úvodní variantní projekt & $\checkmark$ & $\checkmark$ \\
\hline & Technický projekt & $\checkmark$ & $\checkmark$ \\
\hline & $\begin{array}{l}\text { Konstrukční připrava } \\
\text { prototypu }\end{array}$ & $\checkmark$ & $\checkmark$ \\
\hline & Výroba a zkoušky & & \\
\hline & Příprava výroby & $\checkmark$ & \\
\hline \multirow{4}{*}{ 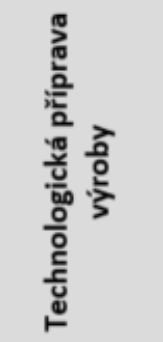 } & $\begin{array}{l}\text { Zpracování technologických } \\
\text { postupů }\end{array}$ & & \\
\hline & $\begin{array}{l}\text { Zpracování výrobních a } \\
\text { montážních návodek }\end{array}$ & $\checkmark$ & $\checkmark$ \\
\hline & $\begin{array}{l}\text { Příprava výroby speciálního } \\
\text { nářadí }\end{array}$ & & \\
\hline & Technicko-hospodárské normy & & \\
\hline \multirow{4}{*}{ 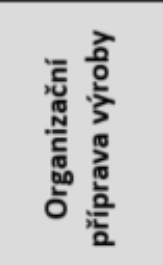 } & $\begin{array}{l}\text { Variantní technicko- } \\
\text { organizační projekt }\end{array}$ & $\checkmark$ & \\
\hline & Výroba ověřovací série & & \\
\hline & Zkoušení a ověřování & & \\
\hline & Vystavení dokumentace & & \\
\hline
\end{tabular}

Autor v Tabulce 1 vychází ze znalostí načerpaných z odborné literatury a vlastní zkušenosti $z$ realizace projektů $v$ průmyslových podnicích. Jak je $v$ tabulce vidět, využití moderních technologií v konstrukční přípravě má široké možnosti a již se hojně používá. Autor by se ale chtěl dále zaměřit především na technologickou prípravu výroby, kde se moderní imerzní technologie hodí hlavně pro zpracování výrobních a montážních postupů. $\mathrm{Na}$ rozdíl od Hořejšího [8], který manuály a návodky řadí do výrobní fáze, autor by chtěl vyzdvihnout možnost jejich použití již ve fázi předvýrobní. Tam má totiž paralelizace přípravných činností největší význam.

Dalším z důvodu, proč si autor tuto oblast vybral je, že s prípravou a zaváděním nového či inovovaného produktu přichází velká rizika. Se čtvrtou průmyslovou revolucí se mění koncept výroby. Průmyslové společnosti se snaží zjednodušovat výrobní procesy tak, aby se snižovala potřebná kvalifikace lidských zdrojů. Schopnosti výrobních a montážních pracovníků se pak stávají nejslabším článkem výroby. [10]

\section{Závěr}

Tento článek se zabýval moderními vizualizačními nástroji a jejich využitím v průmyslu, především v TPV. Popsány byly obecné možnosti využití imerzních technologií $v$ průmyslu. Autor dále navrhl využití moderních nástrojů $v$ technické přípravě výroby. 
Autor se dále zaměřil na technologickou př́ípravu výroby a tedy na použití VR a AR pro tvorbu návodek. Výzkumy provedené na ZČU prokazují, že moderní nástroje mohou mít pozitivní dopad na provádění výrobních procesủ. Tyto a další výzkumy prokázaly, že využitím moderních nástrojů Ize zefektivnit nejen proces učení, ale i zamezit rizikům chybné interpretace pracovního postupu.

Otázkou však zůstává, zda jde tyto výsledky paušalizovat. Testování totiž probíhala za specifických podmínek. Podmínky v praxi se ale budou lišit, což ovlivní i efektivitu provádění výrobních procesů. Autor je názoru, že ne vždy bude mít využití těchto technologií $v$ technické prípravě výroby pozitivní dopad. Výrobní procesy mají mnoho charakteristických faktorů, jež budou mít vliv nejen na rozhodnutí, zda bude využití imerzní technologie pro návodku vhodné, ale i jaký typ návodky bude vyhovovat daným podmínkám. Proto navrhuje zanalyzovat charakteristiky výrobních procesů a jejich vliv na výběr typu návodky.

\section{Poděkování}

Tento článek byl vytvořen za podpory interního grantu ZCU, SGS-2018-031 s názvem Optimalizace parametrů udržitelného výrobního systému.

\section{Použitá literatura}

[1] Roubal, J. Řízení nákladů během životního cyklu produktu. Disertační práce, PIzeň: ZČU v PIzni, 2010.

[2] Šulák, M., Vacík, E. Strategické řizení v podnicích a projektech. 1. vyd. Praha: Vysoká škola finanční a správní, 2005. 233 s. ISBN 80-86754-35-9.

[3] Milton D. Rosenau. Successful Project Management. New York: John Wiley and Sons, 1998. ISBN 0-471-29304-0.

[4] Fotr, J., Souček, I. Investiční rozhodování a řízení projektů: jak pripravovat, financovat a hodnotit projekty, ř́dit jejich riziko a vytvářet portfolio projektů. 1. vyd. Praha: Grada, 2011. 408 s. ISBN 978-80-247-3293-0.

[5] Heřman, J. Řízení výroby. Slaný: Melandrium, 2001. ISBN 80-861-7515-4.

[6] Jurová, M.. Organizace prípravy výroby. 2. vyd. Brno: Akademické nakladatelství CERM, 2015. ISBN 978-80-214-5247-3.

[7] Cearley, D. W., Burke, B., Searle, S., Walker, M. J. Top 10 strategic technology trends for 2018. Gartner Research [online]. 2017 [cit. 2019-0812]. Dostupné z: https://www.gartner.com/en/doc/3811368-top-10-strategictechnology-trends-for-2018

[8] Hořejší, P. Využití virtuální a rozšířené reality v průmyslových podnicích. Habilitační práce, Plzeň: ZČU v Plzni, 2019.

[9] Görner, T., Hořejší, P., Kurkin, O. VYZTYMDP : Virtuální realita: úvodní úroveň, e-book, Smartmotion, 2012. ISBN 978-80-87539-07.

[10] Korecký, M., Trkovský, V. Management rizik projektů: se zaměřením na projekty v průmyslových podnicích. 1. vyd. Praha: Grada Publishing, 2011. 583 s. ISBN 978-80-247-3221-3. 